\title{
Assessing salt-stress tolerance in barley
}

\author{
Somasundaram Rajeswari ${ }^{1, *}$, Neeru Sood, Trupti Gokhale Swarup, \\ Ramachandran Subramanian
}

Edited by

Juan Carlos Salcedo-Reyes

(salcedo.juan@javeriana.edu.co)

1. Birla In itute of Technology and

Sciences, Pilani, Department of

Biotechnology, Dubai Campus.

*srajeshwari@dubai.bits-pilani.ac.in

Received: 23-01-2018

Accepted: 13-9-2018

Published on line: 04-03-2019

Citation: Rajeswari S, Sood N,

Gokhale ST, Subramanian R.

Assessing salt-stress tolerance in barley,

Universitas Scientiarum, 24 (1): 91-109, 2019.

doi: 10.11144/Javeriana.SC24-1.asst

Funding:

N.A.

Electronic supplementary material: Supp. 1.

OPEN ACCESS

\begin{abstract}
Identifying naturally existing abiotic-stress tolerant accessions in cereal crops is central to understanding plant responses towards stress. Salinity is an abiotic stressor that limits crop yields. Salt stress triggers major physiological changes in plants, but individual plants may perform differently under salt stress. In the present study, 112 barley accessions were grown under controlled salt stress conditions $\left(1 \mathrm{Sm}^{-1}\right.$ salinity) until harvest. The accessions were then analyzed for set of agronomic and physiological traits. Under salt stress, less than $5 \%$ of the assessed accessions (CIHO6969, PI63926, PI295960, and PI531867) displayed early flowering. Only two ( $<2 \%)$ of the accessions (PI327671 and PI383011) attained higher fresh and dry weight, and a better yield under salt stress. Higher $\mathrm{K}^{+} / \mathrm{Na}^{+}$ratios were maintained by four accessions PI531999, PI356780, PI452343, and PI532041. These top-performing accessions constitute naturally existing variants within barley's gene pool that will be instrumental to deepen our understanding of abiotic-stress tolerance in crops.
\end{abstract}

Keywords: Agronomic trait; barley; salt stress; yield parameters

\section{Introduction}

Salinity affects crops worldwide. In arid and semi-arid environments, salinity's negative effects on crops are exacerbated by high temperature and inadequate water supply. FAO estimated that approximately $20 \%$ of the world's agricultural land is saline [1]. Further, inadequate agricultural practices lead to salinization of approximately 2000 hectares of land in arid and semi-arid areas per day [2]. Salinity alters a plant's water and mineral nutrient (osmotic and ionic) balance, and prolonged exposure to salinity leads to changes in the molecular and biochemical mechanisms controlling plant development, growth and reproduction [3]. Salinity-induced changes 
in plants, are modulated by changes in gene expression [4]. Facing an unrelenting salinization of agricultural land, the best way to increase crop production is by planting salt-tolerant and high yielding accessions [5, 6]. To this end, we must first identify, by reliable screening procedures, naturally existing salt-tolerant accessions in crop gene pools.

Barley (Hordeum vulgare) is the most salt tolerant cereal crop [7], and it is the fourth most important cereal crop grown worldwide due to its nutritional and health benefits [8]. Barley is also a model crop because of its agronomic, molecular and genetic diversity, which has been exploited and developed since ancient times [9]. Barley is copious in genetic diversity entailed in many landraces and progenitor species. Thus, barley exhibits variation for traits of agricultural importance, such as high yield, resistance to infections, tolerance to abiotic stressors like drought, salt, cold etc. As environmental conditions become more limiting for agriculture, the natural adaptability of cereal crops, like barley ought to be constantly assessed.

In the present study, the agronomic, biochemical and yield attributes of 112 barley accessions obtained from USDA were evaluated for salt stress tolerance under field condition in Dubai to find the salt tolerant accessions.

\section{Materials and methods}

Controlled salt stress experiments were carried out in the field at BITS Pilani, Dubai Campus (25.2048 latitude north, 55.2708 east) in the United Arab Emirates. Dubai is classified as an arid environment. The study was conducted during the 2015-16 winter season (Nov-Feb). The experimental growth field, of size $120 \mathrm{~m}$, was prepared to maintain suitable conditions for efficient irrigation and to get maximum sunlight for plant growth. The field was leveled by plowing and removal of large stones. Since, desert soil is not suitable for plant growth because of its very high sand and salt concentration $(106 \mathrm{mM})$ with electrical conductivity (ECe) of 1056 and a negligible amount of organic matter. Hence a new layer of commercial sweet soil ( $0.5 \mathrm{~m}$ deep) was laid over the sand. This prevents plant roots from directly contacting the underlying highly saline desert soil during the trial. Sweet soil's pH and ECe were determined using saturated paste extract [10] and they were 7.2 and $0.045 \mathrm{Sm}^{-1}$, respectively. The field was irrigated with fresh water $\left(0.003 \mathrm{Sm}^{-1}\right)$ for three days to keep it moist before planting. Grass was grown around the trail field to buffer edge effects. An experiment was carried out on a complete randomized block design with five replicates.

A total of 112 barley accession obtained from the United States Department of Agriculture (USDA) were assessed in this study. Barley accessions 
originated from Africa (Algeria, Egypt, Ethiopia, and Morocco); America (Canada, Peru, and the USA); Asia (Bhutan, China, India, Israel, Japan, Nepal, Saudi Arabia, Pakistan, the Russian Federation, and Syria); Europe (Croatia, England, Germany, Hungary, Norway, Sweden, and Ukraine); and Oceania (Australia). The accessions comprised an array of agronomic categories, such as cultivars, genetic material, breeding material, landraces, and untested results of selection endeavors (henceforth referred to as uncertain improvement). All the accessions were further classified by row type (two-row or six-row or irregular), caryopsis type (covered or hull-less), and growth habit (spring or winter or facultative; Table 1).

Seeds of each accession were disinfected with $6 \%$ hydrogen peroxide and rinsed with distilled water. Sterilized seeds were germinated on moist petri plates at room temperature. Radicle emergence was considered as a sign of germination. Subsequently seedlings were planted in the prepared field. Each accession was planted in a separate raised garden bed of length $0.44 \mathrm{~m}$ and breadth $0.1 \mathrm{~m}$. All beds were spaced $0.3 \mathrm{~m}$ apart. Seedlings were irrigated with fresh water $\left(\mathrm{ECe} 0.003 \mathrm{Sm}^{-1}\right)$ twice a day until they reached their 3-leaf stage.

One liter of freshwater was mixed with $5.8 \mathrm{~g}$ of sodium chloride to make $100 \mathrm{mM}, 1 \mathrm{Sm}^{-1}$, saline water. One fraction of the plants was irrigated with the prepared saline water, and the remainder, control group, received freshwater. This treatment was applied for 91 days, until grains matured and then all plants were harvested. Background soil salinity was $1.545 \mathrm{Sm}^{-1}$ and $0.105 \mathrm{Sm}^{-1}$ for salinity treated and control field.

A set of morpho-agronomic, yield, and physiological traits were assessed on harvested barley. Three plants per accession per treatment (control and $1 \mathrm{Sm}^{-1}$ salt treatment) were harvested to obtain data on agronomic traits including plant height, leaf length and width, total fresh and dry weight, number of fertile and non-fertile tillers, and number of filled grains. Also, sodium and potassium ion content $\left(\mathrm{Na}^{+}\right.$and $\left.\mathrm{K}^{+}\right)$were measured.

Plant height was determined by measuring main culm length. The main culm of all seedlings was tagged before the appearance of tiller(s). Tillers were identified as they emerged from the main culm in an alternate pattern, typically including leaves and leaf sheath. Leaf length was measured from the base to the tip of the blade. Leaf width was also measured at the widest portion of the blade. Productive tillers were those that produced spikes with or without filled grains. Yield parameters like fresh and dry weight, 1000 grains weight, the mean number of spikelet and productive tillers were considered for evaluation. The weight if 1000 grains was determined per 
Table 1. Number of barley accessions per origin, agronomic and phenotype category as used in the present study.

\begin{tabular}{|c|c|c|c|c|c|c|c|c|c|c|c|c|c|}
\hline \multirow[t]{2}{*}{ Origin } & \multicolumn{5}{|c|}{ Category } & \multicolumn{3}{|c|}{ Rowed type } & \multicolumn{2}{|c|}{ Caryopsis } & \multicolumn{3}{|c|}{$\begin{array}{c}\text { Growth } \\
\text { habit }\end{array}$} \\
\hline & 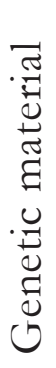 & 苞 & 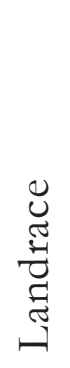 & 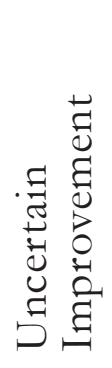 & 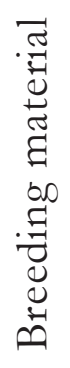 & $\stackrel{B}{B}$ & $\stackrel{\Perp}{\infty}$ & 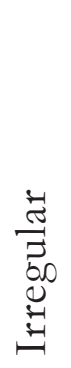 & 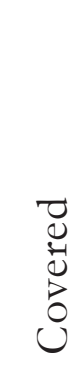 & 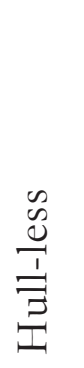 & 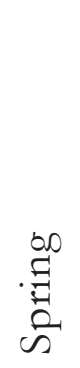 & $\begin{array}{l}\stackrel{ \pm}{ \pm} \\
\stackrel{\Xi}{\Xi} \\
:\end{array}$ & 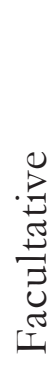 \\
\hline Asia & - & 8 & 14 & 7 & - & 4 & 22 & 3 & 23 & 6 & 4 & 25 & - \\
\hline Australia & - & - & - & 1 & - & - & 1 & - & 1 & - & 1 & - & - \\
\hline America & 1 & 9 & 2 & 1 & 2 & 2 & 13 & - & 15 & - & 12 & 1 & 2 \\
\hline Europe & 1 & 7 & 4 & 2 & 24 & 5 & 29 & 4 & 36 & 2 & 36 & 1 & 1 \\
\hline Africa & - & - & 18 & 11 & - & 11 & 13 & 5 & 28 & 1 & 29 & - & - \\
\hline
\end{tabular}

accession. Spikelet fertility was defined as the ratio of filled grains to a total number of grains in the panicle $[11,12]$. The Mean number of spikelets was calculated from the total number of grains divided by the number of main culms.

All barley leaves and leaf sheaths per plant were separated and weighed immediately after harvest to determine their initial weight. Samples were then dried at $353.15{ }^{\circ} \mathrm{K}$ in a natural convection oven (jEC JSON 400, Chungchungnam-Do, Republic of Korea) until they reached a constant dry weight. Next, dried leaf sheaths per plant were ground to powder and $50 \mathrm{mg}$ of which were digested in $25 \mathrm{ml}$ of $3 \% \mathrm{HNO}_{3}$ and filtered through qualitative grade ash-free filter paper. The estimation of potassium $\left(\mathrm{K}^{+}\right)$and sodium $\left(\mathrm{Na}^{+}\right)$ions concentration was carried out using Inductively Coupled Plasma Optical Emission Spectroscopy. Through this approach accessions were 
ranked according to their response to salinity. The percent relative reduction approach was also used as an index to compare the results according to their response levels to salt stress. Features indicating salt stress tolerance were healthy plant without necrosis, tip drying, or chlorosis.

The salinity susceptibility index (SSI), which accounts for the effect of the salt treatment on a given measured trait, was calculated with the following formula: $S S I=\frac{A s-A c}{S I I(A s)}$, where As and Ac are the values of a given agronomic trait (see measured traits above) of a given accession in salt stress and control conditions, respectively. SII is the salinity intensity index, calculated as $S I I=1-\frac{X S}{X N}$, where $X S$ and $X N$, are the means of all accessions under salt stress and control, respectively. The SSI assesses the relative performance of an accession with respect to the mean performance of all the accessions.

\section{Statistical analysis}

Differences among treatments and accessions for the set of measured traits were assessed with ANOVA. Plant height was further analyzed using Duncan's multiple range test. Agronomic and yield traits were studied by principal component analysis (PCA) as implemented in IBM SPSS statistics v 22.0 (SPSS Inc., 2007, Chicago, IL, USA) for windows. PCA is used to identify key variable sets to define salt tolerant accessions [13, 14].

\section{Results}

We observed substantive variation among all tested 112 barley accessions for all measured morpho-agronomic traits. All barley accessions were ranked from 1 to 7 for salt stress tolerance, based on their average physiological and yield trait values. For a given trait, the highest salt stress tolerance was graded with 1, whereas a score of 7 represented the most susceptible plants. All salt tolerance ranks are defined and presented in Table 2. Maximum, minimum and average values for these agronomic and yield traits under $1 \mathrm{Sm}^{-1}$ salinity treatment are presented in Table 3. For instance, the coefficient of determination on barley spikelet mean number revealed that $61 \%$ of the variation for this trait can be attributed to its corresponding salinity susceptibility index. Moreover, $56 \%$ of the variation in the number of filled grains can be attributed to the salinity susceptibility index for this trait $[15$, 16].

In most accessions, salinity had a negative effect on yield-related traits. The experimental salinity level of $1 \mathrm{Sm}^{-1}$ led to a significant $(\mathrm{p}<0.01)$ reduction on yield-related trait values. Under this salinity level, 72 out of the 112 accessions failed to produce spikes (Suppl. 1. provides the details on the 
Table 2. Ranking for 112 barley accessions collected from USDA for salinity tolerance based on the agronomic trait from the field t rail u nder salinity treatment.

\begin{tabular}{|c|c|c|c|c|c|c|c|}
\hline Rank & $\begin{array}{l}\text { Nun } \\
\text { of } g\end{array}$ & $\begin{array}{l}\text { aber } \\
\text { rains }\end{array}$ & $\begin{array}{l}\text { Height of } \\
\text { the plants } \\
\text { (cm) }\end{array}$ & $\begin{array}{l}\text { Notable } \\
\text { tolerance }\end{array}$ & $\begin{array}{l}\text { Concentration } \\
\text { of } \mathrm{Na}^{+} / \mathrm{Dry} \\
\text { weight of leaf } \\
\text { sheath }(\mathrm{mg} / \mathrm{g})\end{array}$ & $\begin{array}{c}\text { Concentration } \\
\text { of } \mathrm{K}^{+} / \mathrm{Dry} \\
\text { weight of leaf } \\
\text { sheath }(\mathrm{mg} / \mathrm{g})\end{array}$ & $\begin{array}{c}\mathrm{K}^{+} / \mathrm{Na}^{+} \\
\text {ratio in } \\
\text { leaf sheath }\end{array}$ \\
\hline 1 & 181 & 190 & $>70$ & Present & $0-1$ & $91-100$ & $30-35$ \\
\hline 2 & 171 & 180 & $60 \quad 70$ & - & $1.1-2$ & $81-90$ & $25-30$ \\
\hline 3 & 161 & 170 & $50 \quad 60$ & - & $2.1-3$ & $71-80$ & $20-25$ \\
\hline 4 & 151 & 160 & $40 \quad 50$ & - & $3.1-4$ & $61-70$ & $15-20$ \\
\hline 5 & 141 & 150 & $30 \quad 40$ & - & $4.1-5$ & $51-60$ & I0 - 15 \\
\hline 6 & 131 & 140 & $20 \quad 30$ & - & $5.1-6$ & $41-50$ & $5-\mathrm{I} 0$ \\
\hline 7 & 121 & 130 & I0 - 20 & - & $6.1-7$ & $31-40$ & I - 5 \\
\hline 8 & 111 & 120 & $<10$ & - & $7.1-8$ & $21-30$ & $<1$ \\
\hline 9 & 101 & 110 & - & - & $8.1-9$ & $11-20$ & - \\
\hline 10 & \multicolumn{2}{|c|}{$<100$} & - & Absent & $9.1-10$ & $0-10$ & - \\
\hline
\end{tabular}

accessions that produced spikes). Moreover, the total number of spikes, the number of fertile and non-fertile spikes, the number of grains per spike, and the number of inflorescences produced were all affected by the salt treatment. Salinity also affected the lifespan of accessions ClHO15510, PI383011, PI531924, and PI531999; these accessions flowered but died before producing grains. In contrast, under the salt treatment, accessions CIHO6969, PI63926, PI295960, and PI531867 flowered early. The tested level of salinity led to production of non-fertile spikes only in eight accessions 
Table 3. Maximum, minimum and average values for a set of agronomic and yield parameters across all assessed barley accessions grown under salinity.

\begin{tabular}{lllll}
\hline $\begin{array}{l}\text { Agronomic and yield } \\
\text { parameters }\end{array}$ & Minimum & Maximum & Average & $\begin{array}{l}\text { Standard } \\
\text { deviation }\end{array}$ \\
\hline Plant height (cm) & 10.33 & 83.5 & 46.92 & 36.58 \\
\hline $\begin{array}{l}\text { Number of leaves per } \\
\text { main culm }\end{array}$ & 8.00 & 8.00 & 8.00 & 0 \\
\hline $\begin{array}{l}\text { Number of tillers per } \\
\text { plant }\end{array}$ & 0 & 24.00 & 1.60 & 12.00 \\
\hline Amount of $\mathrm{Na}^{+}(\mathrm{mg} / \mathrm{g})$ & 0.246 & 9.431 & 3.251 & 4.593 \\
\hline Amount of $\mathrm{K}^{+}(\mathrm{mg} / \mathrm{g})$ & 3.89 & 95.68 & 24.89 & 45.89 \\
\hline $\begin{array}{l}\text { Number of fertile } \\
\text { spikes per plant }\end{array}$ & 0 & 32.00 & 4.39 & 7.00 \\
\hline $\begin{array}{l}\text { Number of non-fertile } \\
\text { spikes per plant }\end{array}$ & 0 & 16.00 & 4.50 & 5.50 \\
\hline $\begin{array}{l}\text { Total number of spikes } \\
\text { per plant }\end{array}$ & 0 & 21.00 & 2.70 & 12.00 \\
\hline $\begin{array}{l}\text { Number of grains per } \\
\text { spike }\end{array}$ & 0 & 40.00 & 4.14 & 16.00 \\
\hline \begin{tabular}{l} 
Flag leaf length (cm) \\
\hline Flag leaf width (cm)
\end{tabular} & 12.90 & 45.00 & 7.20 & 7.01 \\
\hline $\begin{array}{l}\text { Total fresh weight }(\mathrm{g}) \\
\text { 1000 seed weight }(\mathrm{g})\end{array}$ & 1.29 & 2.100 & 1.10 & 0.33 \\
\hline
\end{tabular}

(CIHO3384, CIHO7143, CIHO7391, CIHO10648, PI145693, PI286406, PI308143, and PI356780). None of the eight accessions produced spikes with filled grains [17]. 
The number of filled grains varied among the accessions that produced spikes. In 18 of these accessions, under the salt treatment we observed a reduction in the number of filled grains from $41 \%$ to $98 \%$ with respect to controls. The number of grains produced per spike ranged from 4 to 40 . For example, accessions CIHO3384 and CIHO15773 recorded a $98 \%$ and an $81 \%$ reduction in spikelet fertility under the salt treatment, respectively. We observed several cases in which the number of grains remained the same in control and salinity treatment for accessions. A better performance on the number of grains per spike was noted in accessions PI531867, CIHO6969, PI15773, and PI5873. These accessions produced $63 \%, 26 \%, 33 \%$ and $80 \%$ more grain under salt treatment than their controls. A total of 15 accessions produced mature grain under the salt treatment, whereas their respective controls were still in their vegetative growth during the same period. Outstanding accessions and its rank for the desirable character exhibited were listed in Table 4.

We observed a significant $(p<0.01)$ reduction in the number of tillers under the salt treatment. A total of 62 accessions failed to produce tillers. Salinity reduced the number of productive tillers (from $20 \%$ to $82 \%$ ) in 90 accessions in comparison to controls. We observed three accessions in which the number of tillers was higher under the salt treatment than in their controls, namely accessions PI145693 and PI286406 produced $40 \%$ more tillers than their controls, and accession PI1531999 produced 21 tillers (100\% more) on salinity treatment compared to its control.

Salinity treatment had a highly significant $(p \leq 0.01)$ effect on traits such as seedling survival, 1000 seed weight, plant height, fresh and dry weight. In the case of flag leaf length and flag leaf width, the effects of salinity were significant at $\mathrm{p}<0.05$. Salinity affected mean plant height in 52 accessions, leading to a reduction from $1.5 \%$ to $65 \%$ in plant height with respect to controls. Accession PI532038, with plant height $44 \mathrm{~cm}$, showed a $65 \%$ reduction due to salt stress. Average plant height was unaffected by salinity in eight accessions, namely CIHO10648, CIHO10953, CIHO15549, PI63926, PI182600, PI383098, PI452324, and PI452420. Remarkably, 51 accession outperformed their controls for plant height in the salinity treatment. More than $50 \%$ increase in plant height was noted in 21 accession. Under salt treatment accessions PI452343, PI429883, and PI532041 outperformed their controls for plant height by $97 \%, 83 \%$, and $76 \%$, respectively. However, these three accessions failed to produce spikes under salinity treatment. The number of leaves produced in the main culm was unaffected by salinity. In all accessions a total of eight leaves, including the flag leaf, were produced in the main culm in both control and salt treatment. 
Table 4. List of accessions in which plants under salt treatment outperformed controls for yield and physiological traits.

\begin{tabular}{|c|c|c|c|c|c|c|c|}
\hline $\begin{array}{l}0 \\
0 \\
0 \\
0 \\
0 \\
0 \\
0 \\
U\end{array}$ & 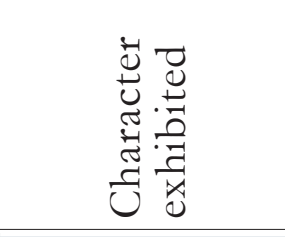 & 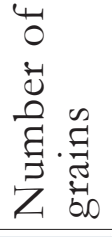 & $\begin{array}{l}200 \\
00 \\
\Xi \\
E \\
{ }^{+} \\
Z\end{array}$ & $\begin{array}{l}\overparen{b 0} \\
00 \\
\Xi \\
E \\
\underline{I}\end{array}$ & 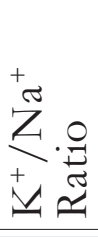 & 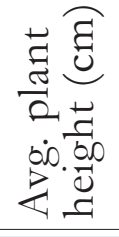 & 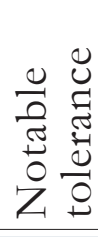 \\
\hline PI5873 & Higher yield & 1 & 4 & 7 & 5 & 10 & 1 \\
\hline СlHO6969 & $\begin{array}{l}\text { Early } \\
\text { flowering }\end{array}$ & 9 & 4 & 8 & 6 & 7 & 1 \\
\hline ClHO15773 & Higher yield & 1 & 2 & 10 & 7 & 10 & 1 \\
\hline PI63926 & $\begin{array}{l}\text { Early } \\
\text { flowering }\end{array}$ & 2 & 10 & 9 & 7 & 8 & 1 \\
\hline PI145693 & More tiller & 5 & 7 & 10 & 8 & 10 & 2 \\
\hline PI286406 & More tiller & 5 & 2 & 8 & 4 & 2 & 2 \\
\hline PI295960 & $\begin{array}{l}\text { Early } \\
\text { flowering }\end{array}$ & 3 & 5 & 5 & 5 & 6 & 1 \\
\hline PI327671 & High biomass & 3 & 4 & 9 & 6 & 6 & 2 \\
\hline PI356780 & $\begin{array}{l}\text { Higher } \\
\mathrm{K}^{+} / \mathrm{Na}^{+}\end{array}$ & 0 & 3 & 5 & 3 & 3 & 2 \\
\hline PI383011 & $\begin{array}{l}\text { Higher } \\
\text { biomass }\end{array}$ & 8 & 2 & 8 & 5 & 8 & 1 \\
\hline PI429883 & Taller & 9 & 6 & 4 & 5 & 1 & 2 \\
\hline PI452343 & $\begin{array}{l}\text { Higher } \\
\mathrm{K}^{+} / \mathrm{Na}^{+} \text {, tall }\end{array}$ & 9 & 2 & 7 & 1 & 1 & 2 \\
\hline PI531867 & $\begin{array}{l}\text { Early } \\
\text { flowering and } \\
\text { higher yield }\end{array}$ & 1 & 2 & 8 & 4 & 7 & 1 \\
\hline PI531999 & High $\mathrm{K}^{+} / \mathrm{Na}^{+}$ & 0 & 2 & 7 & 1 & 1 & 1 \\
\hline PI532041 & $\begin{array}{l}\text { Kigh } \mathrm{K}^{+} / \\
\mathrm{Na}^{+} \text {, taller }\end{array}$ & 6 & 2 & 6 & 3 & 1 & 2 \\
\hline
\end{tabular}

Under control conditions, accessions PI182677 and GSH1653 revealed the highest and lowest dry weights, respectively. Furthermore, under salt treatment, accession PI452336 revealed the lowest dry weight. In contrast, accessions PI327671 and PI 383011 produced the highest biomass, as revealed 
by their dry weights. Regarding physiological traits, we observed the highest $\mathrm{K}^{+} / \mathrm{Na}^{+}$ratios of $34.33,24.61,30.58$, and 21.78 in accessions PI531999, PI356780, PI452343, and PI53204, respectively. Under salinity treatment these accessions grew $2 \%$ to $3.75 \%$ taller than their controls. Similarly, these accessions had higher $\mathrm{Na}^{+}$in their leaf sheaths, revealing necrosis and chlorosis in their leaf tissues. In many of the accessions, $\mathrm{K}^{+}$was accumulated in leaf sheath tissues in variable levels, but in general its concentration was significantly low. The accession CIHO15773 recorded the lowest accumulation of $\mathrm{K}^{+}(3.889 \mathrm{mg} / \mathrm{g})$, while GSHO1653 recorded the highest value for $\mathrm{K}^{+}$content $(95.68 \mathrm{mg} / \mathrm{g})$. Accession PI270603 and PI63926 showed the lowest and highest accumulations of $\mathrm{Na}^{+}(0.246 \mathrm{mg} / \mathrm{g}$ and $9.431 \mathrm{mg} / \mathrm{g})$, respectively.

The $\mathrm{K}^{+} / \mathrm{Na}^{+}$concentration ratio is central to understanding salt stress tolerance in barley. We observed that plants accumulating higher levels of $\mathrm{K}^{+}$in the leaf sheath were more tolerant to salt stress. Accessions PI452343, PI452336 and PI531999 had $\mathrm{K}^{+} / \mathrm{Na}^{+}$ratios 33, 30 and 34 respectively, ranking highest of all the accessions. Accessions PI145693 and PI429962 accumulated more $\mathrm{Na}^{+}$than $\mathrm{K}^{+}$ions in their leaf sheaths. Therefore, their $\mathrm{K}^{+} / \mathrm{Na}^{+}$ratios were below 1. Under salt treatment these two accessions experienced a $50 \%$ - $70 \%$ reduction in plant height compared to their respective controls.

Multivariate statistics were applied to identify accessions with comparable performances for the set of measured traits [15]. Cluster analysis by the Ward's method classified the 112 accessions based on their amounts of leaf sheath $\mathrm{K}^{+}$and $\mathrm{Na}^{+}$under stressed conditions and their $\mathrm{K}^{+} / \mathrm{Na}^{+}$ratios. Two major groups could be distinguished (Fig. 1). Notably, within these group, accessions show minimum variance $[18,19]$.

These two clusters were formed based on $\mathrm{K}^{+} / \mathrm{Na}^{+}$ratios and amounts of $\mathrm{K}$. The first major cluster, in which accession with the highest $\mathrm{K}^{+} / \mathrm{Na}^{+}$ ratios were grouped, was further divided into four sub-clusters with 2, 6, 19, and 11 accessions. Accessions GSHO2361 and GSHO1653 grouped together in the smallest sub-cluster, characterized by exhibiting exceptionally very high concentrations of $\mathrm{K}^{+}(93.33 \mathrm{mg} / \mathrm{g}$ and $95.37 \mathrm{mg} / \mathrm{g})$ in their leaf sheaths. The other three minor clusters were defined by high $(55-68 \mathrm{mg} / \mathrm{g})$ and moderate $(23-43 \mathrm{mg} / \mathrm{g})$ leaf sheath $\mathrm{K}^{+}$content and by high $\mathrm{K}^{+} / \mathrm{Na}^{+}$ratios (6-22; accessions PI356696-PI532041) together with lower leaf sheath amounts of $\mathrm{Na}^{+}(<1.4 \mathrm{mg} / \mathrm{g})$. The second major cluster entailed the remainder $65 \%$ of the accessions and was further divided into three sub-clusters. The division was based on higher amounts of leaf sheath $\mathrm{Na}^{+}$content $(>4 \mathrm{mg} / \mathrm{g})$, lower amounts of $\mathrm{K}^{+}(4-12 \mathrm{mg} / \mathrm{g})$, and lower $\mathrm{K}^{+} / \mathrm{Na}^{+}$ratios (3-4). The number of accessions in each sub cluster were 32,17 , and 25 , respectively. 


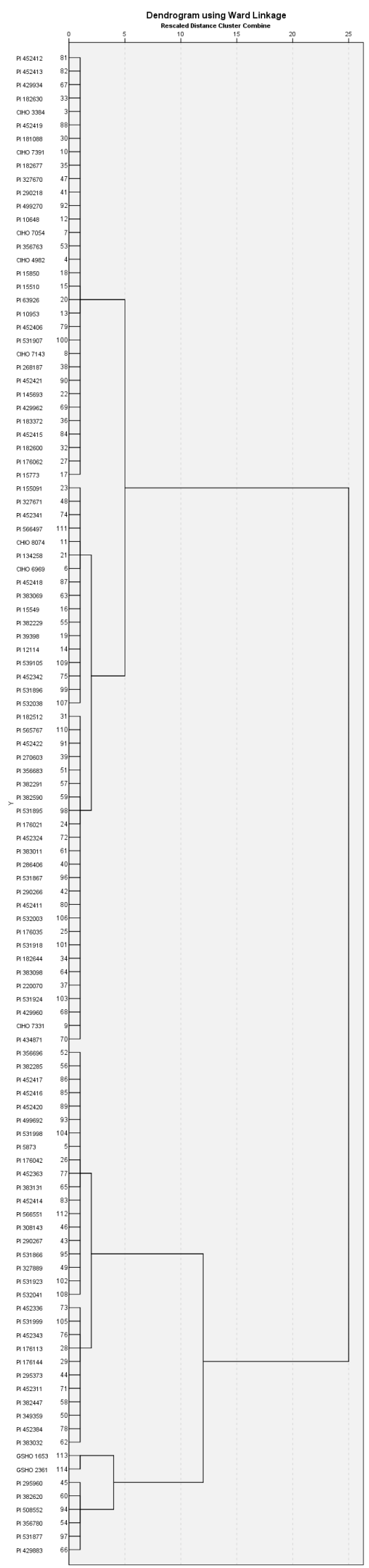

Figure 1. Clusters of similarly performing accessions for $\mathrm{K}^{+} / \mathrm{Na}^{+}$ratio in the leaf sheath under the salinity treatment. 


\section{Discussion}

We grew 112 barley accessions under controlled salt stress conditions and observed variable responses to this stressor in several agronomic, physiological, and yield traits. The effects of salt stress in barley were mainly negative [16]. We observed that salt stress led to a reduction in the number of filled grains per panicle. Also, salt-induced injuries like necrosis, tip drying, and chlorosis were observed in leaves. Consequently, the photosynthetic surface of the plants was reduced. Salinity also induced a shortage-assimilation response evidenced by premature leaf senescence and grain filling [3].

Across all accessions we observed variable sensitivity to salinity, as reflected on the number of spikes per panicle. Furthermore, we noted that salt stress affected both the development and viability of tillers in most of the accessions. The decrease in number of tillers was directly correlated with the amount of $\mathrm{Na}^{+}$accumulated in the plant. Notably, in accessions PI295373 and PI356696 comparable numbers of grains were produced in control and salt treatment plants, and the number of fertile tillers under salinity treatment increased $33 \%$ and $25 \%$, respectively. We also observed cases in which accessions under salt treatment outperformed their controls. For instance, in accessions PI531867, CIHO6969, PI15773, and PI5873, plants under salt treatment produced more grains per spike than their controls.

Flowering is a critical event during barley life cycle, preceding seed production, and it is regulated by both internal and external stimuli. Natural variability exists among accessions for flowering time and stress responses. Intense salt stress triggers early flowering to ensure reproduction [20]; However, premature flowering during stress, may not guaranty a high grain yield [17]. Barley grain yield is directly related to the number of fertile tillers produced per plant. Salinity not only decreased the number of productive tillers and fertile florets per panicle, also it reduced individual grain mass. Crop yield is reduced under stress conditions, due to inhibition of starch synthesis and the inability of the plant to translocate soluble carbohydrates [12].

The height of the tested accessions was significantly altered by salinity. In 103 accessions, height differed between salt treatment and control plants. Comparison of means by Duncan's Multiple Range Test confirmed that salinity stress decreased plant height. The decrease in plant height indicates that salinity affects plant elongation. As the difference in mean value (0.66) between control and salinity treatment is lesser than the tabular values of the significant studentized ranges obtained from the table for 0.05 (0.44) and $0.1(0.6)$ level of significance [21]. 
Salinity altered the mineral content in the leaf sheath of all barley accessions. This overall effect might be due to the ionic imbalance and its toxic nature. Furthermore, barley spikelet fertility decreased, arguably because grains failed to form. This, in turn, is a consequence of the little amounts of viable pollen produced under saline stress conditions [6]. The observed ionic imbalance triggered by salinity directly affected plant total dry weight [5]. The reduction in dry weight directly depends on $\mathrm{Na}^{+}$accumulation. Sodium ions are incompatible with proteins and other macromolecules in the cell. At higher salt concentrations water absorption is reduced, altering water potentials and, thereby, reducing plant growth. Plant biomass declines due to excessive accumulation of sodium chloride in chloroplasts, which is often associated with a decrease in photosynthetic rates and growth. Salinity directly reduces the photosynthetic surface of the plant leading to lower yields [22]. The significantly high amount of $\mathrm{Na}^{+}$in the leaf sheath of accessions PI270603 and GSHO1653 suggests that the mechanism blocking $\mathrm{Na}^{+}$transfer into growing tissues is ineffective at high salt concentrations. These two accessions accumulated more $\mathrm{Na}^{+}$than $\mathrm{K}^{+}$and were regarded as susceptible to salt stress. Only a small number of accessions maintained high levels of $\mathrm{K}^{+}$under saline conditions. $\mathrm{K}^{+}$is essential for cell growth, osmoregulation, ion homeostasis; and $\mathrm{K}^{+}$regulates turgidity during salt stress [23].

Based on leaf sheath $\mathrm{K}^{+} / \mathrm{Na}^{+}$ratios of the 112 accessions, a cluster analysis was conducted. Thanks to this approach we were able to identify accessions with similar performance for this trait $[19,18]$. The two major clusters of the dendrogram and its internal groups evidenced the amount of phenotypic variation within this set of barley accessions. The dendrogram in Fig. 1. revealed that the accessionÂt's physiological performance under saline stress can be assessed by comparing $\mathrm{Na}^{+}$vs $\mathrm{K}^{+}$accumulation. The accessions with higher $\mathrm{Na}^{+}$ions failed to maintain higher $\mathrm{K}^{+} / \mathrm{Na}^{+}$ratios. Conversely, accessions that maintain higher $\mathrm{K}^{+}$can maintain higher $\mathrm{K}^{+} / \mathrm{Na}^{+}$ratios in their leaf sheath. This trait can be further employed as a physiological proxy to identify and monitor salt stress tolerant accessions.

\section{Conclusion and recommendation}

Only a handful of all tested barley accessions achieved highest performance for a set of yield and physiological traits under controlled salt stress conditions. Accession CIHO6969, PI63926, PI295960, and PI531867 showed early flowering and accessions PI327671 and PI383011 achieved higher biomass and better yield. The highest $\mathrm{K}^{+} / \mathrm{Na}^{+}$ratios were attained by accessions PI531999, PI356780, PI452343, and PI532041. These accessions are examples of naturally existing variation for salt-stress tolerance in barley. 
These accessions can be considered as starting material to further study salt stress tolerance in this import crop.

\section{Acknowledgement}

The authors would like to thank United States Department of Agriculture for their generosity providing the seeds for this work.

\section{Conflict of interest}

The authors declare having no conflict of interest.

\section{References}

[1] FAO land and plant nutrition management service. Available on line at: http://www.fao.org/ag/, FAO, 2011. [Online].

[2] Qadir M, Quillérou E, Nangia V, Murtaza G, Singh M, Thomas R, Drechsel P, Noble A. Economics of salt-induced land degradation and restoration, A United Nations Sustainable Development Journal, 38(4): 282-295, 2014.

doi: 10.1111/1477-8947.12054

[3] Gupta B, Huang B. Mechanism of salinity tolerance in plants: physiological, biochemical, and molecular characterization, International Journal of Genomics, 2014: 1-18, 2014.

doi: 10.1155/2014/701596

[4] Munns R. Genes and salt tolerance: bringing them together, New Phytologist, 167(3): 645-663, 2005.

doi: 10.1111/j.1469-8137.2005.01487.x

[5] Oyiga BC, Sharma RC, Shen J, Baum M, Ogbonnaya FC, Léon J, Ballvora A. Identification and Characterization of Salt Tolerance of Wheat Germplasm Using a Multivariable Screening Approach, Plant Cell \& Environment, 41: 919-935, 2016.

doi: $10.1111 /$ jac.12178

[6] Hoang TML, Tran TN, Nguyen TKT, Williams B, Wurm P, Bellairs S, Mundree S. Improvement of Salinity Stress Tolerance in Rice: Challenges and Opportunities, Agronomy, 54(4): 1-23, 2016. doi: 10.3390/agronomy6040054 
[7] Shahid M, Jaradat A. Barley: A salt tolerant cereal crop, Biosalinity News, 14: 3-4, 2013.

[8] Zannini E, Arendt E. Cereal Grains for the Food and Beverage Industries, Sawston, Cambridge: Woodhead Publishing Limited, 2013.

[9] Wang Y, Ren X, Sun D, Sun G. Origin of worldwide cultivated barley revealed by NAM-1 gene and grain protein content, Frontiers in Plant Science, 803(6): 1-12, 2015.

doi: 10.3389/fpls.2015.00803

[10] McKenzie RC, Chomistek W, Clark NK. Conversion of electromagnetic inductance readings to saturated paste extract values in soils for different temperature, texture and moisture conditions, Canadian Journal of Soil Science, 692(1): 25-32, 1989.

doi: 10.4141/cjss89-003

[11] Razack M A, Lee T. Characterization of Rice (Oryza sativa L.) Physiological Responses to a-Tocopherol, Glycine Betaine or salicylic Acid Application, Journal of Agricultural Science, 3(1): 3-13, 2011.

doi: $10.5539 /$ jas.v3n1p3

[12] Yamakawa H, Hakata M. Atlas of Rice Grain Filling-Related Metabolism under High Temperature: Joint Analysis of Metabolome and Transcriptome Demonstrated Inhibition of Starch Accumulation and Induction of Amino Acid Accumulation, Plant and Cell Physiology, 51(5): 795-809, 2010.

doi: $10.1093 / \mathrm{pcp} / \mathrm{pcq} 034$

[13] Johnson RA, Wichern DW. Applied Multivariate Statistical Analysis, 6th ed., New Jersey: Prentice-Hall, 2007.

[14] Muhammad Zubair, Saif Ullah Ajmal, Muhammad Anwar, Haqqani A M. Multivariate analysis for quantitative traits in mungbean [Vigna radiate (L.) Wilczek], Pakistan Journal of Botany, 39: 103-113, 2007.

[15] Mohammadi SA, Prasanna BM. Analysis of genetic diversity in crop plants--Salient statistical tools and considerations, Crop Science, 43: 1234-1248, 2003.

doi: $10.2135 /$ cropsci2003.1235

[16] Gill KS. Effect of soil salinity on grain filling and grain development in barley, Biologia Plantarum, 21(4): 241-244, 1979.

doi: 10.1007/BF02902204 
[17] Kazan K, Lyons R. The link between flowering time and stress tolerance, Journal of Experimental Botany, 67: 47-60, 2016.

doi: $10.1093 / j x b / e r v 441$

[18] Jaynes DB, Kaspar TC, Colvin TS, James DE. Cluster Analysis of Spatiotemporal Corn Yield Pattern in an Iowa Field, Agronomy Journal, 95(3): 574-586, 2003.

doi: 10.2134/agronj2003.5740

[19] Jolliffe IT, Allen OB, Christie BR. Comparison of Variety Means Using Cluster Analysis and Dendrograms, Experimental Agriculture, 25: 259-269, 1989.

doi: 10.1017/S0014479700016768

[20] He G, Mingna J, Xiao-Ming Z, Jun C, Dingyang Y, Yeyun X, Maoqing W, Dongyi H, Zhe Z, Kunneng Z, Peike S, Jin M, Weiwei M, Huafeng D, Ling J, Shijia L, Haiyang W, Chuanyin W, Longping Y, Jianmin W. Days to heading 7, a major quantitative locus determining photoperiod sensitivity and regional adaptation in rice, Proceedings of the National Academy of Sciences, 111(46): 16337-16342, 2014.

doi: 10.1073/pnas.1418204111

[21] Data Science Central, Available on line at: http://www. statisticshowto.com/duncans-multiple-range-test, 2017. [Online].

[22] Hanin M, Ebel C, Ngom M, Laplaze L, Masmoudi K. New Insights on Plant Salt Tolerance Mechanisms and Their Potential Use for Breeding, Frontiers in Plant Science, 7: 1-17, 2016.

doi: 10.3389/fpls.2016.01787

[23] Munns R, Tester M. Mechanisms of salinity tolerance, Annual Review of Plant Biology, 59: 651-681, 2008.

doi: 10.1146/annurev.arplant.59.032607.092911 


\section{Determinación de la Tolerancia al estrés por salinidad en la cebada}

Resumen. La identificación de accesiones existentes en condiciones naturales que sean tolerantes al estrés abiótico en cultivos de cereales es fundamental para entender las respuestas al estrés. La salinidad es un factor de estrés abiótico que limita el rendimiento de los cultivos. El estrés por salinidad desencadena importantes cambios fisiológicos en las plantas, pero plantas individuales pueden comportarse diferencialmente bajo este tipo de estrés. En el presente estudio se hicieron crecer 112 accesiones de cebada bajo condiciones controladas de estrés por salinidad (1 $\mathrm{Sm}^{-1}$ salinidad) hasta la cosecha. Posteriormente las accesiones se analizaron para determinar sus caracteres agronómicos y fisiológicos. Bajo condiciones de estrés por salinidad, menos del $5 \%$ de las accesiones estudiadas (CIHO6969, PI63926, PI295960 y PI531867) mostraron floración temprana. Solamente dos $(<2 \%)$ de las accesiones (PI327671 y PI383011) alcanzaron mayores pesos fresco y seco y un mayor rendimiento bajo estrés por salinidad. Se mantuvieron mayores proporciones $\mathrm{K}^{+} / \mathrm{Na}^{+}$en cuatro accesiones PI531999, PI356780, PI452343 y PI532041. Estas accesiones que tuvieron el mejor rendimiento constituyen las variantes existentes en condiciones naturales dentro del acervo genético de la cebada, que pueden ser instrumentos para profundizar en nuestro entendimiento de la tolerancia de los cultivos al estrés abiótico.

Palabras clave: caracteres agronómicos; cebada; estrés por salinidad; parámetros de rendimiento 


\section{Determinação da tolerância ao estresse por salinidade na cevada}

Resumo. A identificação de acessões existentes em condições naturais que sejam tolerantes ao estresse abiótico em culturas de cereais é fundamental para entender a resposta ao estresse. A salinidade é um fator de estresse abiótico que limita o rendimento das culturas. O estresse por salinidade desencadeia importantes mudanças fisiológicas nas plantas, no entanto, plantas individuais podem se comportar diferentemente sob este tipo de estresse. No presente estudo 112 acessões de cevada foram cultivadas sob condições controladas de estresse por salinidade $\left(1 \mathrm{Sm}^{-1}\right.$ salinidade) até a colheita. Porteriormente, as acessões foram analizadas para determinar suas características agronômicas e fisiológicas. Sob condições de estresse por salinidade, menos de $5 \%$ das acessões estudadas (CIHO6969, PI63926, PI295960 e PI531867) mostraram floração prematura. Somente duas (< $2 \%$ ) acessões (PI327671 e PI383011) atingiram maiores pesos frescos e secos e um maior redimento sob estresse por salinidade. As maiores proporções $\mathrm{K}^{+} / \mathrm{Na}^{+}$ foram mantidas em quatro acessões PI531999, PI356780, PI452343 e PI532041. As acessões com maior rendimento constituem as variantes existentes em condições naturais dentro do fundo genético da cevada, que podem ser instrumentos para aprofundar no nosso entendimento da tolerância dos cultivos ao estresse biológico.

Palavras chave: caracteres agronómico; cevada; estresse por salinidad; parâmetros de redimento 


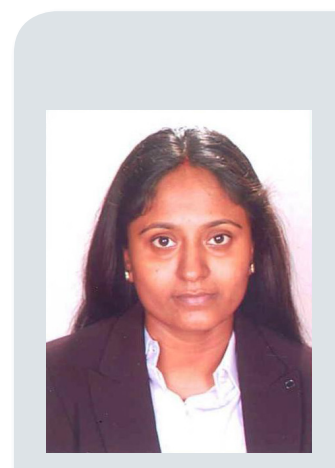

\section{Rajeswari Somasundaram}

Is a Ph.D. scholar working on salt stress response in cereal crops at BITS Pilani, Dubai Campus, UAE. Her research focuses on understanding the metabolic and genetic basis of salt tolerance and protein interaction networks. She has published her work on computational approaches to studying salinity-responsive proteins in millet and gene expression in barley.

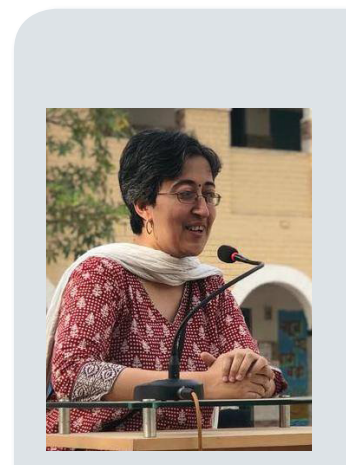

\section{Neeru Sood}

Is associate Dean and researcher at BITS Pilani Dubai Campus. She worked as a Biotechnologist in Nahar Sugar \& Allied Industries. Ltd. Prof. Sood has guided doctoral students and supervised several inter-disciplinary projects. She has coordinated research on stress-tolerant Rhizobial strains at the International Center for Biosaline Agriculture (ICBA), UAE.

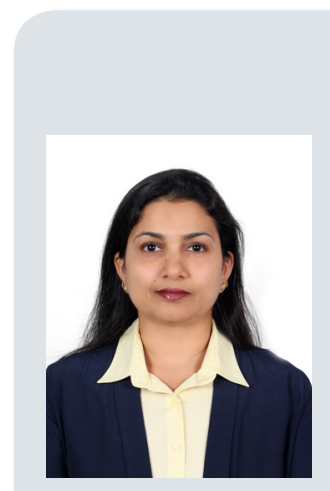

\section{Gokhale Trupti Swarup}

Is a microbiologist conducting research on the synthesis of metal nanoparticles in bacteria, and on the development of biodegradable plastics from bacterial sources. Dr. Gokhale has also worked on biofertilizers using the native Rhizobia of UAE and was first to demonstrate their existence in the region. She has also worked on establishing the presence of an alternate oxidase pathway for respiration in the micro-algae Dunaliella salina and rice under salt stress.

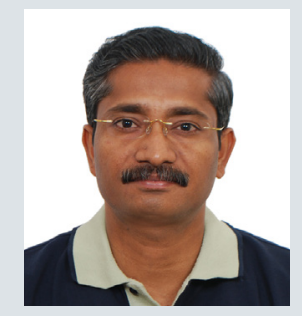

\section{Ramachandran Subramanian}

Is associate professor of Biotechnology, Department of Biotechnology, at the Birla Institute of Technology and Science, Pilani, Dubai Campus, UAE. His research interests include bioremediation, environmental biotechnology and biomass-based biofuel production. 